\title{
C-40 LOWER CONGO BASIN, DEEPWATER EXPLORATION PROVINCE, OFFSHORE WEST AIRICA
}

DA COSTA', J. LEITE', T.W. SCHIRMER ${ }^{2}$ and B.R. LAWS ${ }^{2}$

'Sonangol

${ }^{2}$ Chevron Overseas Petroleum Inc., Luanda, Angola

\begin{abstract}
The Lower Congo Basin lies offshore of the west coast of Africa and covers 115,000 square kilometers from the Republic of Congo to central Angola, in water depths extending to over 3500 meters. A large number of oil and gas fields occur in the basin (14 MMMBOEG produced and proven).
\end{abstract}

Two main producing trends have been discovered. The first, discovered in Block 0 in Cabinda, Angola over 30 years ago, produces from Cretaceous reservoirs in water depths less than 200 meters.

In the past four years, approximately 50 exploratory and appraisal wells have been drilled in the Lower Congo Basin Tertiary deepwater turbidite trend, which is associated with ancient deepwater channel deposition of the Congo River fan. At least 21 new oil fields have been discovered in the deepwater trend, in water depths between 200 and 1500 meters. Threedimensional seismic data is the key to mapping these complex turbidite channel prospects. Significant areas of this new province remain undrilled, with numerous channels and trap features. Structural traps (fault truncations, channel drape over structural highs, and salt domes) dominate. Reservoirs are complex high quality turbidite sand systems. Source rocks occur in three separate intervals (Cretaceous Bucomazi and Iabe, and Tertiary Malembo formations).

The first field to produce from the turbidite trend - Kuito field in Block 14, Cabinda, Angola, discovered in April 1997 by Chevron (Operator) and partners Sonangol, Agip, Total, and Petrogal- went on production in December 1999.

\section{Introduction}

A series of conditions have converged in time to produce one of the most competitive and successful exploration plays in recent history of the oil business. These conditions are:

- The recognition of geologic elements conducive to hydrocarbon occurrence in a new area

- Active, world class petroleum system with multiple source rocks.

- Widely distributed, excellent quality, deepwater turbidite sandstone reservoir rocks

- Complex tectonic history with salt dynamics, producing multiple structural trends and a myriad of traps across the basin

- Advances in technology which enable exploration and development of oil fields in deepwater settings

- Support of the government for the petroleum industry in Angola 
These conditions have converged in the Lower Congo Basin deepwater trend, and the world's oil companies have come to Angola to chase this new and exciting exploration play that has opened up what promises to be a major oil-producing province.

The Lower Congo Basin is presently one of the hottest and most successful exploration plays in the world. Continuous announcements of discoveries have taken place over the last several years in Blocks 14, 15, 16,17 and 18 in Angola, and Haute Mer in the Republic of Congo. Technical risk in the deepwater trend appears to be very low with 36 exploration wells drilled, 25 potential discoveries that encountered testable hydrocarbons, and up to 21 commercially developable accumulations. These are remarkable numbers and have driven the excitement and competition in the basin.

Several fields announced to date have been characterized as giant accumulations with recoverable reserves of $500 \mathrm{MMBO}$ or greater. The mean size of fields discovered to date is at least $200 \mathrm{MMBO}$ of recoverable reserves. Several fields are vertically stacked, and grouped geographically around structural traps. These characteristics will enable production facilities to tap multiple accumulations, adding to the value of the facilities through time. Fields in this basin will benefit from recent advances in deepwater development technology that enable production in greater than 1000 meters of water. As exploration progresses into prospective areas with water depths up to 3500 meters, this basin will provide the impetus for further advances in engineering technology to produce the reserves. The benign ocean environment characteristic of this portion of the western coast of Africa will enable technology to push to greater water depths than might be practical in more adverse environments. Once infrastructure is in place in the deepwater across the basin, satellite fields and smaller accumulations will become commercially viable.

Most of the basin has been covered with modern 3-dimensional seismic data over the last five years. When combined with the powerful computer hardware and software now available to visualize and interpret the data, this has enabled a high level of understanding of the geology and prospectivity of the deepwater trend.

The companies involved in this play have aggressively taken leases and drilled wells in the deepwater trend in the Lower Congo Basin of Angola and the Republic of Congo, but significant areas of the basin remain undrilled.

\section{Geologic Setting}

The Lower Congo Basin lies offshore of the west coast of Africa and covers 115,000 square kilometers from the Republic of Congo to central Angola, in water depths extending to over 3500 meters. The Lower Congo Basin is within the Congo Basin proper, which is a sub-basin of the Aptian Salt Basin system that occurs along the western coast of Africa.

The history of the Congo Basin can be divided into three main stages:

1. Rift stage, with lacustrine and alluvial deposition within graben and half-graben structural basins (Neocomian to mid-Aptian)

2. Evaporite deposition stage, developed during the transition from active rifting to thermallyinduced crustal subsidence (Aptian)

3. Subsidence stage, with regional marine deposition and active extension and salt tectonics (Albian to Recent) 
Continued subsidence during this third phase provided significant accommodation space for a large volume of Tertiary sediment into the Congo Basin. The highest sedimentation rate occurred during the Miocene, with up to $6000 \mathrm{~m}$ of section deposited in the Malembo Formation. The large volume of sediment was deposited from the Congo River, which drains a vast area of south central Africa.

Throughout the Miocene, the Congo River spread submarine turbidite deposits across the basin, with the vector of sedimentation varying with time within an arc from the southwest to northwest. Deposition of the deepwater turbidite facies occurs in a channel-dominated submarine fan system. Regional assessments by Chevron tie the depositional sequence to the Miocene sealevel curves and provide a methodology to model and predict depositional geometry and sand content. Sand systems are generally deposited at sequence boundaries in cut and fill channels with internal meandering geometry common, and variable net:gross of sand content both vertically and laterally. Some channel systems exhibit more linear channel/levee geometry. Differential compaction is evident on seismic data in higher net:gross intervals and where channel meanders are stacked vertically. Outside of channel systems the predominant sediment is shale, forming vertical and lateral seals to sand-filled channels.

Extension and compression along the regional Aptian salt detachment continued throughout the Tertiary and strongly influenced deposition of turbidites. Depocenters formed which collected turbidite deposits through time, providing stacking of channel systems. Some growth occurred after deposition, with channels crossing structure with little or no deflection and salt domes piercing channels. This relationship of concurrent deposition and structural growth across the basin has enhanced the potential for numerous traps. These traps are associated with rollover into extensional faults; channel truncation against updip faults; compaction closures over deeper Cretaceous-cored structures; and traps over and around salt domes, salt-cored thrusted folds, and turtle structures. In general, structural traps with a component of stratigraphic trapping dominate in the basin. Structural deformation continues today with examples of sea bottom expression of salt domes and surface scarps of active faults.

\section{Exploration History}

A large number of oil and gas fields occur in the Congo Basin. Two main productive trends have been discovered. The first, the Cretaceous pre-salt and post-salt trend, stretches 350 kilometers along the coastline in water depths less than 200 meters, from the Republic of Congo to central Angola. The second occurs in the Lower Congo Basin deepwater Tertiary turbidite trend and stretches 300 kilometers from the Haute Mer block in the Republic of Congo to Block 18 in central Angola, in water depths greater than 200 meters. Although the Cretaceous producing trend has been explored for over 30 years, additional exploratory potential exists with acquisition of new 3-dimensional seismic data. The Tertiary deepwater turbidite trend is not mature, with three-quarters of the prospective area of the trend still undrilled. Further drilling will certainly expand the Tertiary deepwater turbidite trend significantly.

The first field to produce from the turbidite trend is Kuito field in Block 14, Cabinda, Angola, discovered in April 1997 by Chevron (Operator) and partners Sonangol, Agip, Total, and Petrogal. The field lies in about 350 meters of water. Production is through subsea wells to a central FPSO with export directly from offshore. The field began production in December 1999, and is expected to reach 100,000 BOPD in 2001. 


\section{Future Potential}

Within the primary deepwater trend explored over the last four years (Blocks 14-18 in Angola and Haute Mer in the Republic of Congo), 36 exploratory wells occur in an area of approximately 24,000 square kilometers, with a well density of one well per 660 square kilometers. Three-dimensional seismic data is the key to mapping the complex turbidite channel prospects in the Lower Congo Basin, and since this part of the trend is essentially covered by 3D surveys, it is likely that continued drilling within this area will discover new fields.

Significant areas of this new province remain undrilled, with numerous channels and trap features. Approximately 60,000 square kilometers of highly prospective acreage with play elements consistent with the successful Tertiary prospects in the present trend are completely unexplored. This unexplored area lies outboard of Blocks 14-18 in Angola and Haute Mer in the Republic of Congo, in water depths from 1500-3500 meters.

Given the Lower Congo Basin success rate to date within the combined structural/stratigraphic traps, and the large area still unexplored with the same characteristics, it is likely that near term exploration will focus on these types of features. Sometime in the future, the subtle and pure stratigraphic traps will likely be understood and contribute to the prospectivity of the basin.

The existence of significant areas of subsalt will create a challenge to those companies prospecting for turbidite plays. The decrease in quality of the seismic imaging and spatial location of prospects beneath the salt overhangs will raise the geologic risk of wells, but the existence of the petroleum system and turbidite channels bordering these areas to the east means the subsalt area is still highly prospective. Companies with experience in the Gulf of Mexico subsalt play can leverage that experience to better handle the seismic imaging challenges, more accurately locate wells, and evaluate predrill risk appropriately.

The Lower Congo Basin is a world class petroleum province with giant fields discovered and significant areas still unexplored. It is probable that additional giant fields wait to be discovered in the basin, as well as a full distribution of fields of various sizes. 